\title{
Gastrointestinal Stromal Tumor Pathologic Regional Lymph Nodes TNM
} Finding v8

National Cancer Institute

\section{Source}

National Cancer Institute. Gastrointestinal Stromal T umor Pathologic Regional Lymph Nodes TNM Finding v8. NCI Thesaurus. Code C136764.

A pathologic finding about one or more characteristics of gastrointestinal stromal tumor, following the rules of the TNM AJCC v8 classification system as they pertain to staging of regional lymph nodes. 